\title{
Living Landscape: The European Landscape Convention in Research Perspective
}

\section{Bas Pedroli, Marc Antrop e Teresa Pinto Correia}

Editorial : This special issue reports some of the highlights of the conference Living Landscape - The European Landscape Convention in Research Perspective, organised jointly by UNISCAPE and Landscape Europe (UNISCAPE, 2010). Starting questions for this conference were: what has science contributed to the implementation of the European Landscape Convention (CoE, 2000) and what are the topics for the future of European landscape?

The 10th anniversary of the Florence Convention in October 2010 was an opportunity to discuss the merits of landscape science in integrated research of a rapidly changing environment. Many interdisciplinary contributions presented referred to the Landscape Convention. The conference focused on cutting-edge research results at the crossroads of sciences and humanities, design and empiricism. Not by chance, the conference was also the occasion to launch a new ESF-COST Science-Policy Briefing on Landscape Research (Bloemers, Daniels, Fairclough, Pedroli, \& Stiles, 2010 Bloemers, T., Daniels, S., Fairclough, G., Pedroli, B., \& Stiles, R. (Eds.) (2010) Landscape in a changing world. Bridging Divides, integrating disciplines, serving society. Science Policy Briefing $\mathrm{nr}$ 41. Strasbourg and Brussels: ESF-COST.

): 'Landscape in a Changing World - Bridging Divides, Integrating Disciplines, Serving Society'. It emphasises the importance of four interdisciplinary themes:

Universal commons: securing landscape as a common good.

Roots and routes: coming to terms with mobility and evolving lifestyles.

Reactions and resilience: long-term landscape transformations.

Road maps: landscape as baseline and context for future change.

The papers in this special issue largely reflect these themes.

Keywords; living landscape; European landscape convention; research perspective;

DOI: http://dx.doi.org/10.1080/01426397.2013.873269

Citação: Pedroli, B., Antrop, M., Pinto-Correia, T., 2013. Living landscape: the European landscape convention in research perspective. Landscape Research 38(6): 691-694. http://dx.doi.org/10.1080/01426397.2013.873269 